\author{
Самофратова B.A. \\ кандидат економічних наук, доцент \\ кафедра економіки промисловості \\ Одеська національна академія харчових технологій \\ вул. Канатна, 112, м. Одеса, Україна, 65039 \\ E-mail: vica_samofatova@mail.ru
}

\title{
АДАПТИВНЕ УПРАВЛІННЯ ПОТЕНЦІАЛОМ СТАЛОГО РОЗВИТКУ ПІДПРИЄМСТВ ХАРЧОВОЇ ПРОМИСЛОВОСТІ
}

У статті акцентовано увагу на низці важливих питань, пов'язаних з з процесом адаптації до нових та постійно мінливих умов господарювання підприємств харчової промисловості. В роботі проаналізовані завдання подальшого удосконалення управління потенціалом сталого розвитку підприємств харчової промисловості України.

Ключові слова: харчова промисловість; підприємство; прибуток; адаптивне управління; сталий розвиток.

This work is licensed under a Creative Commons Attribution 4.0 International License http://creativecommons.org/licenses/by/4.0/

Постановка проблеми та її зв'язок з важливими науковими та практичними завданнями. За Аристотелем дійсним стає тільки те, що має можливість стати дійсним [Т.1, с.15]. Харчова промисловість України - це багатогалузевий комплекс, який об'єднує близько 25 видів діяльності, має значні внутрішні резерви для економічного зростання, водночас ще не повністю реалізує свої можливості в формуванні і використанні внутрішнього продовольчого та експортного потенціалів. Важливою характеристикою світового ринку, є швидкий темп змін у зовнішньому середовищі. Сьогодні, основне завдання менеджменту полягає в тому, щоб передбачити будь-які зміни і підготувати заздалегідь відповідну реакцію підприємства. Такі зміни можуть бути радикальними та, найчастіше, еволюційними, спрямованими, наприклад, на розробку нових видів продукції, модифікацію існуючих або впровадження екологоенергетичного менеджменту на підприємствах.

Аналіз останніх публікацій 3 проблеми. Аналіз наукової літератури свідчить про активну розробку даної проблеми. Проблеми сталого розвитку та управління потенціалом промислових підприємств досліджувались у працях таких вчених як I. Должанський, Л. Корнійчук, С. Лапін, Л. Мельник, П. Осіпов [3], І. Смачило [9], О. Шубравська та інших дослідників. Проблемам гнучкого, адаптивного управління присвячені роботи С. Алексєєва, Р. Бєкмуратова [6], М. Буднік , Н. Зяблицької [4], С. Кравченко, Н. Кулик [2], О. Меліх, Н. Туріци [5]. Проте, незважаючи на високу значимість проаналізованих наукових досліджень, існує потреба у створенні адаптивної системи управління сталим розвитком підприємств харчової промисловості.

Формулювання цілей дослідження. Метою статті є дослідження технології адаптивного процесу управління, формування механізму та системної моделі адаптивного управління потенціалом сталого розвитку підприємств харчової промисловості України.

Виклад основних результатів і їх обгрунтування. Концепція сталого розвитку (sustainable development) $\epsilon$ продовженням концепції ноосфери, сформульованої академіком В. Вернадським, ще в першій половині XX ст. III сутність полягає в обов'язковій узгодженості економічного, екологічного та людського розвитку. Для того, щоб якість і безпека життя людей, не зменшувалась для прийдешніх поколінь, не погіршувався стан довкілля та відбувався соціальний прогрес, який враховує потреби кожної людини. Оскільки природа і природні ресурси є основою життєдіяльності людини, їхнє виснаження та деградація за існуючих економічних відносин негативно відображаються на соціальних відносинах, структурі виробництва та споживання.

До основних факторів виробництва та економічного розвитку в класичній економічній науці відносять капітал, працю та землю. Розвиток економіки світу призвів до формування нових факторів виробництва - ресурсів управління та науки. Підприємство як об'єкт управління це складна, динамічна, виробнича, соціально-економічна, технічна i організаційна система, відкрита до впливу зовнішнього середовища. У виробничому процесі підприємства поєднуються різні матеріальні і трудові ресурси, між якими існує безліч зв'язків (рис.1).

Сутність управління полягає у досягненні підприємством його мети при мінімальному використанні ресурсів і максимальному виході цільового продукту. Основна мета діяльності підприємства отримання прибутку та розвиток. 


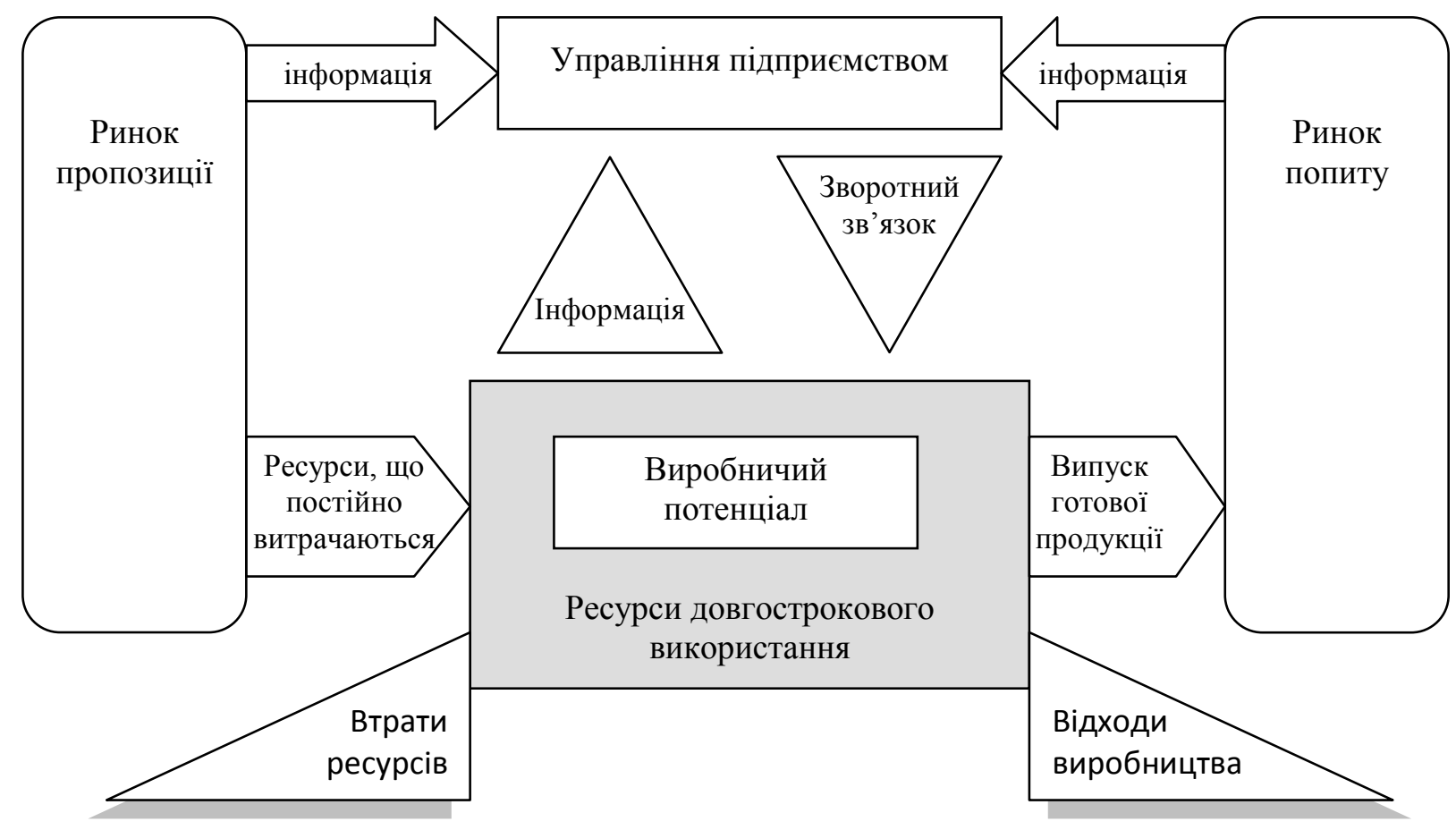

Рис.1. Модель функціонування підприсмства харчової промисловості [авторська розробка]

Дослідники виділяють найбільш важливі фактори, які дозволяють вітчизняним підприємствам адаптуватись до змін умов зовнішнього середовища [2, с. 98$]$, [9, с. 12]:

- технічні - перехід від традиційних до високих технологій;

- структури потреб - зниження матеріало- та енергомісткості виробленої продукції при збереженні iii споживчих властивостей, значне підвищення якості та надійності споживчих властивостей товарів, підвищення культури споживання;

- виробничі - створення великих компаній 3 високим рівнем диверсифікації виробництва, навколо яких формується мережа підприємств малого та середнього бізнесу, орієнтація на розвиток виробничої кооперації в межах та поза межами регіону, формування інтелектуального потенціалу регіону.

Поняття «потенціал» прийшло в економіку з фізики, а «адаптація» - 3 біології. Взагалі, в кінці XX сторіччя 3'явилось багато комплексних наук. Водночас, поняття енергії пов'язує їх та всі інші явища природи в одне ціле. У роботі П.В. Осіпова «Інтегральний виробничий потенціал харчової промисловості» економічний потенціал підприємства представляє собою максимально можливу ефективність ресурсновиробничого потенціалу, яка може бути досягнута на основі максимальної ефективності елементів виробництва, що формують ресурсно-виробничий потенціал. Сприйняття досягнень науково-технічного прогресу, спроможність розвитку шляхом безпосереднього та ефективного використання інноваційних технічних i технологічних рішень $є$ визначальною ознакою потенціалу підприємства [3, с.84]. До чинни- ків адаптації підприємств, також можуть бути віднесені: особливості орієнтації в соціальноекономічному просторі, активність управлінського апарату, креативність рішень, уміння робити вибір, моделювання багатоваріантності розвитку. Адаптація - це спосіб не тільки виживання, але і подальшого сталого розвитку підприємств.

Адаптивний потенціал підприємства, на думку Зябліцької Н.В., характеризує досягнутий рівень виробництва, соціальну і фінансово-економічну здатність, конкурентоспроможність та сталість розвитку [4, с.31]. Концептуально солідарна 3 нею й Туріца Н.А., яка формулює поняття адаптивного потенціалу «як сукупні можливості організації з приводу оптимального використання наявних ресурсів 3 метою забезпечення іiі конкурентоспроможності і економічного зростання (розвитку системи) в сучасних економічних умовах» $[5$, с.16].

Необхідно зазначити, що в економічній літературі не склалося однозначного тлумачення предмету адаптивного управління. На думку більшості авторів, воно розглядається як сукупність дій i методів, що характеризуються здатністю управляючої системи реагувати на зміну зовнішнього середовища. Проте, на думку Бєкмуратова Р.Д «адаптивна система управління - це система управління організацією, котра передбачає можливість і здатність підприємства в залежності від зміни зовнішнього середовища та внутрішніх факторів зберігати стійкість організації в довгостроковій перспективі та забезпечувати необхідний рівень конкурентоспроможності підприємства і продукції» [6, с.24]. 
Багато вітчизняних підприємств харчової промисловості, які мали налагоджену систему виробничо-господарської діяльності, планування та обліку, виявилися нездатні адекватно і усвідомлено реагувати на постійно мінливі умови зовнішнього середовища в силу нерозвиненості ринкових інструментів гнучкого, адаптивного управління. Зокрема, у 2015 р. стався спад виробництва більшості видів харчової продукції порівняно з 2014 роком. Найзначніший спад виявився у виробництві: фруктових та овочевих соків (з 440 до 246 тис. т); цукру (з 2053 до 1459 тис. т); шоколаду (з 235 до 183 тис. т); олії соняшникової нерафінованої (з 4400 до 3715 тис. т). Достатню стабільність діяльності продемонстрували галузі: виробництва м'яса птиці (710 - 712 тис. т); виготовлення овочів консервованих натуральних (144 - 145 тис. т); круп (350 - 347 тис. т); їа та страви готові, з макаронних виробів $(95,1-109$ тис. т); води натуральні мінеральні негазовані (36,0 - 36,0 млн. дал) [8]. Водночас,обсяги експорту продукції в ЄС у 2015 р. зросли на $14 \%$, а продукції рослинництва - на 2,4\%. За деякими товарами був продемонстрований значний прогрес. Зокрема, у 2015 році у Свропейський Союз було експортовано рекордні обсяги м'яса птиці, які майже у 2 рази вищі, ніж у 2014 р. У загальноєвропейському імпорті соняшникової олії кожен 7-ий літр - українського виробництва. У 2015 р. на ринок Свропи експортовано 1,5 рази більше томатної пасти, ніж у 2014 р., а постачання цукру зросло у 12 разів [8].

Слід відзначити і вагому роль науковців у зростаючих експортних можливостях м'яса птиці 3 України. Для прикладу, ПАТ «Миронівський хлібопродукт» у тісній співпраці з вченими Одеської національної академії харчових технологій (ОНАХТ) довів, що вітчизняні результати виробництва комбікормів і вирощування м'яса бройлерів можуть бути на рівні світових, а за якістю навіть перевищувати їх. Запровадження сучасних технологій виробництва високоякісних комбікормів, високоефективних рецептів, сучасних екологічно чистих технологій вирощу- вання, дозволили ПАТ «Миронівський хлібопродукт» стати одним із лідерів України з експорту м'яса бройлерів до країн західної Свропи та інших країн світу. Крім того, ПАТ «Миронівський хлібопродукт» останні п'ять років стабільно утримує пальму першості з обсягів виробництва комбікормів в Україні. Розробки одеських та київських вчених відкривають нові можливості для України. Розроблені ними технології, режими, обладнання та системи управління стали основою створення вітчизняної системи енергоефективних технологій зберігання зерна та його переробки в харчові і кормові продукти, а це додаткові мільйони гривен економічного ефекту [8, с. 5].

В даний час, вихід на траєкторію сталого розвитку харчової промисловості можливий лише за умови мобілізації іiі внутрішніх ресурсів, підвищення ефективності виробництва і відповідному рівні розвитку сировинної бази. При цьому слід враховувати, що цілі забезпечення виживання на ринку, максимізація прибутку, утримання ринку та забезпечення сталості суб'єкта економіки нерівнозначні за своїм рівнем. Якщо перші з них логічно віднести до тактичних цілей, то забезпечення потенціалу сталого розвитку - до стратегічних.

Висновки і перспективи подальших досліджень. Підприємства харчової промисловості повинні не тільки виготовляти продукцію, а й стати інтегратором агропродовольчої сфери в цілому. Адаптація підприємств харчової промисловості залежить, насамперед, від ефективного використання їх внутрішнього ресурсного потенціалу і ефективного та адаптивного управління. Реалізація пріоритетів довгострокового розвитку підприємств харчової промисловості, які формуються під впливом зовнішнього середовища, неможлива без внутрішньої перебудови самого підприємства - появи нових функцій і видів діяльності, підвищення його комунікаційної активності, створення умов для управління інтегрованими процесами, комплексного урахування ринкового середовища.

\section{Література}

1. Аристотель. Сочинение в 4 т. / [под ред. В.Ф. Асмус]. - М.: Мысль. - Т. 1. - 1975. - 550 с.

2. Кулик Н.М. Технологія адаптації у системі управління підприємством/ Н.М. Кулик, Т.М. Соколенко // Економічний аналіз : зб. наук. праць; за ред. С. І. Шкарабан та ін. - Тернопіль : Видавничо-поліграфічний центр Тернопільського національного економічного університету “Економічна думка”. - 2013. - № 3, Том 14. C. 96-100.

3. Осипов П.В. Интегральный производственный потенциал пищевой промышленности / П.В.Осипов. - Одесса: Институт проблем рынка и экономико-экологических исследований НАН Украины, 2004. - 289 с.

4. Зяблицкая Н.В. Методология комплексной оценки адаптационного потенциала предприятий нефтегазовой отрасли : автореф. дис. на получение науч. степени докт. эк. наук : спец. 08.00 .05 - «Развитие производственных сил и региональная экономика» / Зяблицкая Н.В. - Санкт-Петербург, 2013. - 42 с.

5. Туріца Н.А. Стратегічні чинники адаптації підприємств до зовнішнього середовища (на прикладі м'ясопереробних підприємств) : автореф. дис. на здобуття наук. ступеня канд. ек. наук : спец. 08.00 .04 - «Економіка та управління підприємствами» / Туріца Н.А. - О., 2009. - 20 с.

6. Бекмуратов Р.Д. Формирование адаптивной системы управления на предприятиях кондитерской отрасли пищевой промышленности АПК: автореф. дис. на получение науч. степени канд. эк. наук: 08.00 .05 «Развитие производственных сил и региональная экономика» / Бекмуратов Р.Д. - Саранск, 2014. - 29 с. 
7. Офіційний сайт Державної служби статистики України. [Електронний ресурс]. - Режим доступу : http://www.ukrstat.gov.ua

8. Соц С.М. Системи технологій у вирішенні проблеми ефективного зберігання та переробки зерна / С.М. Соц // Зернові продукти і комбікорми. - 2015. - №3(259). - С. 4-5.

9. Смачило I.І. Механізм управління сталим розвитком підприємств харчової промисловості : автореф. дис. на здобуття наук. ступеня канд. ек. наук : спец. 08.00.04 - «Економіка та управління підприємствами»/ Смачило I.I. - Тернопіль, 2011. - 20 с.

10. Craig R. Allen, Joseph J. Fontaine, Kevin L. Pope, Ahjond S. Garmestani. Adaptive management for a turbulent future / R. Allen Craig, J. Fontaine Joseph, L. Pope Kevin, S. Garmestani Ahjond // Journal of environmental management. — 2011. - № 92. — C. 1339-1345.

11. Zięba K., Olma S. Efficiency of management of sustainable development - challenges, problems, barriers / K. Zięba, S. Olma // Economic Processes Management: International Scientific E-Journal. - 2016. - № 2. - C. 67-72.

Стаття надійшла 2.08.2016

Стаття прийнята до друку 16.08.2016 Доступно в мережі Internet 30.09.2016

\author{
Самофатова B.A. \\ кандидат экономических наук, доцент \\ кафредра экономики промышленности \\ Одесская национальная академия пищевых технологий \\ ул. Канатная, 112, м. Одеса, Украина, 65039 \\ E-mail:vica_samofatova@mail.ru
}

\title{
АДАПТИВНОЕ УПРАВЛЕНИЕ ПОТЕНЦИАЛОМ УСТОЙЧИВОГО РАЗВИТИЯ ПРЕДПРИЯТИЙ ПИЩЕВОЙ ПРОМЫШЛЕННОСТИ
}

В статье акцентировано внимание на ряде важных вопросов, связанных с процессом адаптации к новым и постоянно меняющимся условиям хозяйствования предприятий пищевой промышленности. В работе проанализированы задачи дальнейшего совершенствования управления потенциалом устойчивого развития предприятий пищевой промышленности Украины.

Охарактеризована концепция устойчивого развития и ее значимость для будущего функционирования пищевой промышленности. Исследовано предприятие как сложную производственную систему и объект управления. Выделены важнейшие фракторы, которые позволяют отечественным предприятиям пищевой промышленности адаптироваться к изменениям условий внешней среды.

Проанализировано понятие экономического и адаптивного потенциала предприятия и раскрыта их взаимосвязь. Рассмотрены подходы к построению адаптивной системы управления на предприятии. Исследовано современное состояние и динамика развития предприятий по изготовлению основных видов пищевой продукции. Охарактеризованы экспортные возможности отраслей пищевой промышленности Украины. Отмечена роль ученых Одесской национальной академии пищевых технологий в росте экономической эффективности производства мяса птицы и увеличении экспортных возможностей.

Отмечено, что выход на траекторию устойчивого развития пищевой промышленности, возможен только при условии мобилизации ее внутренних резервов, повышения эффективности производства, и соответствующем уровне развития сырьевой базы. Акцентировано внимание на том, что предприятия пищевой промышленности должны не только производить продукцию, но и стать интегратором агропродовольственной сферы в целом. Отмечено, что обеспечение потенциала устойчивого развития - стратегическая цель функционирования предприятий пищевой промышленности. Сделан вывод, что адаптация предприятий пищевой промышленности зависит, прежде всего, от эфрективного использования внутреннего ресурсного потенциала и адаптивного управления.

Ключевые слова: пищевая промышленность; предприятие; прибыль; адаптивное управление; устойчивое развитие. 


\author{
Samofatova V. \\ Ph.D. in Economics, Associate Professor \\ Department of Industrial Economics \\ Odessa National Academy of Food Technologies \\ Kanatna str., 112, Odessa, Ukraine, 65039 \\ E-mail: vica_samofatova@mail.ru
}

\title{
ADAPTIVE MANAGEMENT FOR POTENTIAL OF SUSTAINABLE DEVELOPMENT ENTERPRISES OF FOOD INDUSTRY
}

The article focuses on several important issues related to the process of adapting to new and constantly changing economic conditions of the food industry. The work analyzes the problems of further improvement of the management capacity of sustainable development of enterprises of food industry of Ukraine.

Characterized by the concept of sustainable development and its importance for the future functioning of the food industry. Researched enterprise as a complex production system, and the control object. Highlighted the major factors that allow domestic food industry to adapt to changes in environmental conditions.

Analyzed the concept of economic and adaptive potential of the company and disclosed their relationship. The approaches to building an adaptive management system in the enterprise.

Investigated the current state and development dynamics of enterprises for the production of the main types of food products. Characterized by export potential of food industry of Ukraine. The role of scientists of the Odessa national academy of food technologies in the growth of economic efficiency of poultry meat production and increase export opportunities.

It is noted that the sustainable development of the food industry is only possible through the mobilization of its internal resources, improve production efficiency and the appropriate level of resources.

The attention that the food industry should not only produce products, but also become the integrator in the food industry as a whole. It is noted that the capacity of sustainable development - strategic goal of the functioning of the food industry.

It is concluded that the adaptation of the food industry depends primarily on the effective use of domestic resources potential and effective adaptive management

Keywords: food industry, enterprise, profit, adaptive management, sustainable development.

\section{References}

1. Arystotel. (1975). Sochynenye (1st ed., Vol. 4). M.: Musl.

2. Kulyk, N. M., Sokolenko, T. M., \& Shkaraban, S. I. (2013). Tekhnolohiia adaptatsii u systemi upravlinnia pidpryiemstvom. Ekonomichnyi Analiz, 3(14), 96-100.

3. Osypov, P. V. (2004). Yntehralnыi proyzvodstvennыi potentsyal pyshchevoi prombshlennosty. Odessa: Ynstytut problem rыnka y эkonomyko-эkolohycheskykh yssledovanyi NAN Ukraynd.

4. Ziablytskaia, N. V. (2013). Metodolohyia kompleksnoi otsenky adaptatsyonnoho potentsyala predpryiatyi nefte-hazovoi otrasly. Sankt-Peterburh.

5. Turitsa, N. A. (2009). Stratehichni chynnyky adaptatsii pidpryiemstv do zovnishnoho seredovyshcha (na prykladi miasopererobnykh pidpryiemstv). Odessa.

6. Bekmuratov, R. D. (2014). Formyrovanye adaptyvnoi systemb upravlenyia na predpryiatyiakh kondyterskoi otrasly pyshchevoi prombshlennosty APK. Saransk.

7. Ofitsiinyi sait Derzhavnoi sluzhby statystyky Ukrainy. Retrieved from: http://www.ukrstat.gov.ua

8. Sots, S. M. (2015). Zernovi produkty i kombikormy. Systemy Tekhnolohii U Vyrishenni Problemy Efektyvnoho Zberihannia Ta Pererobky Zerna, 3(259), 4-5. Ternopil.

9. Smachylo, I. I. (2011). Mekhanizm upravlinnia stalym rozvytkom pidpryiemstv kharchovoi promyslovosti.

10. Craig, A. R., Joseph, J. F., Kevin, P. L., \& Ahjond, S. G. (2011). Adaptive management for a tur-bulent future. Journal of Environmental Management, 92, 1339-1345.

11.Zięba, K., \& Olma, S. (2016). Efficiency of management of sustainable development - challenges, problems, barriers. Economic Processes Management: International Scientific E-Journal, 2, 67-72. 